\title{
WSPOMNIENIE O KSIĘDZU PROFESORZE WEADYSEAWIE WICHRZE
}

Wspominając Księdza Profesora Władysława Wichra, którego w listopadzie 1969 r. odprowadziliśmy na cmentarz w rodzinnych Krzyszkowicach, wypada osadzić Jego postać w różnych po kolei środowiskach. Wypada zacząć właśnie od tych Krzyszkowic pod Myślenicami, od chłopskiej chaty, gdzie się urodził i wychował i gdzie też po przeszło osiemdziesięciu latach życia pragnął spocząć na zawsze. Krakowskie Gimnazjum św. Anny (później im. Nowodworskiego), Krakowskie Seminarium Duchowne, studia teologiczne naprzód w Krakowie, potem w Innsbrucku, parafie, na których po święceniach kapłańskich i studiach pracował - a wreszcie Wydział Teologiczny Uniwersytetu Jagiellońskiego. I tutaj trzeba się zatrzymać.

Trzeba się zatrzymać nie tylko ze względów biograficznych, bo i życie Profesora na kilkadziesiąt lat - właściwie do końca - związało się z Wydziałem, ale także i z innych, głębszych jeszcze względów, które nadają właściwe znaczenie biografii.

Wydział Teologiczny jest środowiskiem. Jest uczelnią, jest warsztatem pracy naukowej i dydaktycznej, jest poniekąd szkołą życia dla przyszłych kapłanów i duszpasterzy, która - wraz z Seminarium - wprowadza ich na dalekie drogi powołania i misji kościelno-społecznej. Ale przede wszystkim Wydział Teologiczny jest środowiskiem. O tym wiedzą nie tyle ci, którzy przez Wydział przechodzą, ile ci, którzy na nim pozostają. Wiedzą o tym profesorowie, docenci, adiunkci, asystenci - a wiedza ta w miarę lat staje się coraz dojrzalsza, bo coraz ściślej i głębiej obcuje z centralną rzeczywistością tego środowiska, z jego dobrem dogłębnym i wspólnym zarazem. 
Dobrem tym jest nauka. W wypadku Wydziału Teologicznego jest nim teologia. Jednakże zanim powiemy o teologii jako nauce, jako tej nauce, którą przez kilkadziesiąt lat uprawiał Ks. Profesor Wicher, wypada jeszcze dokończyć myśli o nauce, o teologii, jako dobru wspólnym środowiska, któremu na imię Wydział Teologiczny UJ. Srodowisko to tworzyli ludzie, tworzyli je zaś poprzez osobisty i wspólny zarazem stosunek do tej nauki, ad której Wydział brał swoją nazwę - starą, historyczną nazwę, sięgającą Roku Pańskiego 1397. Byli to w okresie profesury Ks. Wichra ludzie o głośnych nazwiskach, znanych w Polsce i świecie. Nie trzeba nawet wymieniać nazwisk, bo samie się przypominają. A przed tymi ludźmi nauki byli inni, całe pokolenia uczonych, aż do Wieku Złotego, do Sredniowiecza. Kiedy mowa o Wydziale Teologicznym UJ jako środowisku, trzeba myśleć historycznie. Wszystkie te pokolenia profesorów, uczonych i nauczycieli, są w nim obecne nie tylko na zasadzie formalnej sukcesji dyscyplin i katedr, ale na zasadzie życiodajnego dziedzictwa i dziedziczenia. Nauka jest dobrem, które się przekazuje i dziedziczy. Dzieje się to zaś nie w sposób rzeczowy tylko, ale i osobowy. Nie tylko w księgach i skryptach, ale w przekazie i odbiorze żywych ludzi. Dziedziczenie to stwarza genealogie uczonych, pomiędzy którymi istnieje więź prawie taka jak więź, która powstaje z rodzenia. Jakieś duchowe ojcostwo i duchowe synostwo związane ze stosunkiem do nauki. Uczony przekazuje uczonemu część swojej duszy, dziedzictwo zamiłowań, a także zawiłe nieraz i trudne drogi, którymi dochodził do prawdy. Równocześnie zaś patrzy, w którym miejscu ten jego przekaz wyda owoce, często odmienne, często innym podyktowane zamiłowaniem, z innej wyrosłe metody, Genealogia uczonych żyje $\mathrm{w}$ środowisku nauki i stanowi o nim.

Ksiądz Profesor Wladysław Wicher $z$ wielkim zainteresowaniem śledził własną genealogię. Stąd powstały takie prace jak Ks. Szymon Stanisław Makowski - moralista polski z XVII w. ${ }^{1}$, Mikotaj z Mościsk teolog moralista $i$ pisarz ascetyczny $z$ pocz. XVII w. ${ }^{2}$, Pozytywizm teologiczny u Jana Makowskiego i Jana Szydłowskiego, teologów kalwińskich XVII w. ${ }^{3}$, O. M. Smigleckiego TJ nauka o lichwie $i$ procentach $w$ świetle wspótczesnej i późniejszej nauki teologów ${ }^{4}$. Wszystko to prace przedwojenne. A po drugiej wojnie śxiatowej: Nauka teologii moralnej $w$ dawnych seminariach misjonarskich ${ }^{5}$, Wplyw św. Alfonsa Liguoriego na teologie moralna $w$ Polsce ${ }^{6}$, Teologia moralna na Wydziale Teologicz-

\footnotetext{
1 Kielce, 1926.

2 Lwów, 1928.

3 Warszawa, 1935.

4 „Collectanea Theologica”, 17 (1936) 290-315. Odb. Lwów, 1936.

5 "Nasza Przeszłość”, 3' (1947) 162-180. Odb. Kraków, 1947.

6 ,Ateneum Kapłańskie”, 47 (1947) 1-13.
} 
nym Akademii Krakowskiej od końca XVII w. ${ }^{7}$. Chyba wystarczy, aby stwierdzić, że był świadom swojej genealogii, że przebadał przeszłość dyscypliny, której sam poświęcił kilkadziesiąt lat życia na katedrze Wydziału Krakowskiego.

Samemu nie było chyba dane przeżyć owego procesu sukcesji naukowej w całej pełni, został bowiem w kilka lat po doktoracie powołany na Wydział z placówki katechetycznej po wczesnej śmierci swego poprzednika, profesora teologii moralnej Ks. Stanisława Zegarlińskiego, o którym się zawsze wyrażał z największym uznaniem. Nie miał jednak czasu współpracować ze swoim poprzednikiem w katedrze uniwersyteckiej, na którą wszedł zrazu jako zastępca profesora. Nieraz mówił o tym, że musiał do wielu osiągnięć w swej dziedzinie dochodzić sam. Poszedł oczywiście za swoimi własnymi zainteresowaniami, a były to jak widać w znacznej mierze zainteresowania historyka teologii. Może odpowiadało to także mocnemu wówczas w Wydziale Krakowskim prądowi do badań historycznych, który reprezentowali jako profesorowie tacy uczeni jak Ks. Jan Fijałek, a w dziedzinie historii filizofii Ks. Konstanty Michalski.

Praca, na podstawie której habilitował się w 1923 r. nosi tytuł Niewolnictwo $w$ nauce moralnej chrześcijaństwa ${ }^{8}$ - a więc zagadnienie systematyczne ale osadzone w historycznym kontekście i historycznych źródłach. Jeżeli jest to również praca $\mathrm{z}$ historii, to $\mathrm{w}$ każdym razie nie tylko $\mathrm{z}$ historii teologii moralnej, ale $\mathrm{z}$ historii moralności. Trzeba bowiem stwierdzić, że Księdza Profesora Wichra jako moralistę interesowała zawsze bardziej żywa moralność, aniżeli sama etyka systematyczna. Nie znaczy to, aby jej rówież nie uprawiał. Wykładał całokształt teologii moralnej, nie tylko część szczegółową ale także i tzw. principia. Interesował go jako moralistę podmiot moralności czyli człowiek, osoba ludzka. Specjalną uwagę poświęcił zagadnieniu wolności woli, czego ślady napotykamy nie tylko w Jego skryptach, ale także w osobnym studium pt. Wolność woli, determinizm psychologiczny jako zagadnienie etyczne $i$ wychowawcze ${ }^{9}$. Pozostawał $\mathrm{w}$ kontakcie $\mathrm{z}$ psychologią, charakterologią i nauką o temperamentach. Wystarczy przejrzeć wydane pośmiertnie Podstawy teologii moralnej ${ }^{10}$, aby się o tym przekonać. Stale $z$ tej dziedziny coś studiował i wprowadzał do swoich wyłładów.

To wszystko uważał za ważne $z$ punktu widzenia owej właśnie żywej moralności, która zawsze zajmowała go najbardziej. Tu szedł za jakimś swoim zasadniczym talentem czy charyzmatem, który bardziej wiązał go z konkretem aniżeli z abstrakcją czy spekulacją w etyce i teologii. Wy-

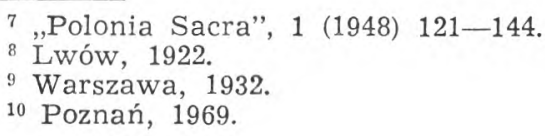

10 Poznań, 1969. 
razem tego były pierwsze prace historyczne. Wyrazem tego liczne prace i publikacje rozsiane przez wiele lat jego profesury na kartach Przeglądu Powszechnego czy też takich czasopism jak Trzeźwość, Caritas, a wreszcie w postaci luźnych druków czy broszur. Wszędzie tam zabierał głos nie tylko jako teolog-moralista, ale jako człowiek troszczący się o autentyczną moralność społeczeństwa. Wystarczy rzucić okiem na tytuły, aby ustalić przedmiot tego zatroskania. Do pewnego stopnia przedmiot ten powtarza się w okresie międzywojennym i powojennym, choć po drugiej wojnie światowej pojawiają się także nowe tematy. Tak więc zagadnienie etyki seksualnej znajdujemy w szeregu publikacji przedwojennych Walka o kiełkujące życie ludzkie 11, Karalność przerywania ciaży ${ }^{12}$, Kilka uwag o nowoczesnej etyce seksualnej ${ }^{13}$, Swiadome macierzyństwo ${ }^{14}$, Moralność seksualna dzisiejszej młodzieży szkolnej ${ }^{15}$. Ten sam temat wróci po wojnie: Jak wychować młodzież, zwłaszcza męska do czystości ${ }^{16}$. Podobnie gdy chodzi o zagadnienie alkoholizmu: Alkoholizm a rodzina ${ }^{17}$, Istota chrześcijańsliiej trzeźwości ${ }^{18}$ - a po wojnie: Wplyw alkoholizmu na życie wewnętrzne ${ }^{19}$.

Interesowała go w okresie przedwojennym również etyczna strona sportu ${ }^{20}$, zagadnienie eugeniki ${ }^{21}$. Natomiast po drugiej wojnie światowej wypłynęły zagadnienia moralne właściwe dla tego okresu. Łatwo je zidentyfikować czytając takie tytuły jak: Chrześcijańska miłość bliźniego $i$ obozy koncentracyjne ${ }^{22}$, Wyrzeczenie się własnej narodowości ${ }^{23}$. Jeżeli ktoś zechciałby zapoznać się z problematyką żywej moralności na przestrzeni tych kilkudziesięciu lat, jeżeli by zechciał prześledzić jej drogi a zarazem niepokoje jakie rodzi refleksja związana z poczuciem odpowiedzialności - to znajdzie to wszystko także $\mathrm{w}$ tej publicystyce profesora teologii moralnej, który był wrażliwy na życie moralne własnego społeczeństwa i czuł się za jego moralność odpowiedzialny.

Wiele okoliczności na to się złożyło. Zapewne działał tutaj i ten przysłowiowy „chłopski rozum", który w zetknięciu ze środowiskiem uniwersyteckim niczego nie utracił, wręcz przeciwnie, zachował całą swoją

11 „Przegląd Powszechny”, 187 (1930) 261-277.

12 "Przegląd Powszechny”, 189 (1931) 21-36.

13 "Przegląd Współczesny”, 40 (1932) 16-30.

14 „Ateneum Kapłańskie”, 34 (1934) 479-489. Odb. Włocławek, 1935

15 "Przegląd Powszechny", 214 (1937) 281-300.

16 Katowice, 1948.

17 „Trzeźwość”, 6 (1931) 165; 234-239.

18 "Trzeźwość", 10 (1935) 105-111.

19 "Caritas", 5 (1949) 79-80.

20 Etyczne granice sportu, „Ateneum Kapłańskie”, 29 (1932) 348-358. Odb. Włocławek, 1932.

${ }_{21}$ Eugenika w świetle zasad chrześcijańskich, „Ruch Katolicki”, 5 (1935) 521-531.

22 „Przegląd Powszechny”, 224 (1947) 42-47.

23 "Przegląd Powszechny”, 225 (1948) 196-207. 
tożsamość. Można powiedzieć, że zawsze stał u podstaw tych wszystkich kategorii, które naniosła wiedza, a przede wszystkim u podstaw tak ważnych dla moralisty rozstrzygnięć. Ow chłopski rozum związany był wszakże $\mathrm{z}$ dziedzictwem zdrowego, trzeźwego sumienia. Niedawno pożegnaliśmy innego Profesora, wielkiego historyka literatury, który opisał swą drogę $Z$ Komborni $w$ świat. Chociaż Ks. Profesor Wicher nie pozostawił analogicznego opisu swej drogi „Z Krzyszkowic w świat”, to przecież trudno się oprzeć jakiejś analogii tych dróg, jakie w tamtym czasie - już przeszłym - odbywali synowie chłopscy $\mathrm{w}$ pierwszym pokoleniu na katedry uniwersyteckie. Trudno zwłaszcza oprzeć się głębokiemu odczuciu, wzbogacenia, jakie łączyło się z tym, że ów „chłopski rozum", a wraz z nim zdrowe i trzeźwe sumienie, stawały u podstaw tworzącej się w tej epoce kultury naszego narodu.

Ta okoliczność wydaje się szczególnie ważna. Ona też może tłumaczy, dlaczego profesor teologii moralnej i prałat, kustosz Kapituły Metropolitalnej w Krakowie chciał spocząc na cmentarzu w rodzinnych Krzyszkowicach. Jakby dawał świadectwo, że stamtąd szczególnie wiele wyniósł i wniósł w całe swoje posłannictwo. Szczególna wrażliwość na moralność własnego społeczeństwa i poczucie odpowiedzialności za nią płynęło także i stąd, że Ks. Profesor Wicher czuł się zawsze jako moralista mocno związany z duszpasterstwem. Funkcję swoją pojmował nie tylko w granicach wykładów i egzaminów (podobno był egzaminatorem raczej łagodnym), ale także jako konsultację dla kierowników sumień i spowiedników. Przez wiele lat odwoływano się do jego instrukcji dla spowiedników w sprawach etyki małżeńskiej i rodzinnej. W tej dziedzinie doskonale wyczuwał kierunek myśli Kościoła i przygotował grunt dla pracy moralistów z okresu II Soboru Watykańskiego oraz encykliki $\mathrm{Hu}$ manae vitae. Oprócz instrukcji pisemnych chętnie służył także osobistą radą, uważając, że do obowiązków moralisty należy rozstrzyganie szczególnie trudnych wypadków w dziedzinie konfesjonału i kierownictwa sumień. Ten dział teologii moralnej ${ }^{24}$ pozostawił sobie najdłużej jako temat wykładów. Wykładał go właściwie do samej śmierci.

Spojrzenie na ludzką moralność w pryzmacie sumienia łączyło się u Ks. Wichra z ujęciem tejże moralności w wymiarach społecznych. Tu trzeba wspomnieć raz jeszcze o tych wszystkich publikacjach, które dotykały węzłowych $\mathrm{z}$ punktu widzenia społecznego problemów w naszej moralności. Pod koniec swojej pracy w katedrze, wiążąc nastawienie moralisty $\mathrm{z}$ doświadczeniem duszpasterza, szukał na drodze wielu prac swoich uczniów - również aktualnych lub przyszłych duszpasterzy możliwie szczegółowego a zarazem i szerokiego spojrzenia na stan reli-

${ }^{24}$ Tzw. casus conscientiae. 
gijno-moralny społeczeństwa. Szedł tutaj parafiami i dekanatami, zalecając wykorzystanie tych źródeł, którymi te jednostki kościelne dysponują. Można się zastanawiać nad wystarczalnością metody. Równocześnie jednak trzeba dostrzec, że w polu widzenia Profesora teologia moralna łączyła się $\mathrm{z}$ badaniami $\mathrm{w}$ dziedzinie socjologii moralności. Tu również znalazła potwierdzenie empiryczna i nastawiona na życiowy konkret orientacja jego umysłowości. Jeśli zaś chodzi o metodę badań i prac, to zrozumiałe, że mogła ona prowadzić tylko do pewnych przyblizien. Ale i przybliżenie do prawdy liczy się $w$ nauce.

Mówiąc o spojrzeniu na ludzką moralność w wymiarach społecznych, trzeba brać pod uwagę nie tylko to, że Księdza Wichra zajmowała moralność społeczeństwa, ale także i to, że nie spuszczał z oka strony społecznej moralności. Wprawdzie katolicka etyka społeczna stanowiła osobną specjalizację na Wydziale i dlatego teolog moralista bezpośrednio się nią nie zajmował. Jednakże żywy stosunek do etyki społecznej, który zaznaczył się już w pracy habilitacyjnej na temat niewolnictwa, powracał zawsze na jego wykładach i seminariach. W czasie tych ostatnich wiele uwagi poświęcił np. pańszczyźnie oraz stosunkowi Kościoła w Polsce do pańszczyzny.

Kreślony tutaj obraz Księdza Profesora Władysława Wichrä jako moralisty przylega do jego życia także i w tym okresie, kiedy — podobnie jak inni profesorowie Almae Matris - został przemocą okupanta odsunięty od katedry uniwersyteckiej. Wraz z nimi przeszedł przez Sachsenhausen, a po powrocie był proboszczem w Dziekanowicach koło Gdowa i dziekanem wielickim. Funkcja proboszczowska pokrywała tajemnicą konspiracji ten kilkuletni okres w dziejach Wydziału Teologicznego UJ, kiedy to - podobnie jak inne wydziały tej Uczelni — również i Wydział Teologiczny prowadził studia w sposób tajemny. W tym okresie Ks. Prałat Wicher był proboszczem, nie przestając być moralistą i czerpiąc z doświadczenia duszpasterskiego nowe światła dla swej moralistyki.

Powiedzieliśmy już, że była to moralistyka żywa i związana z życiem. W tym kierunku prowadziła Profesora cała jego umysłowość. Jest jednak rzeczą znamienną, że książka, która ukazała się w parę tygodni po śmierci Ks. Profesora Wichra, nosi tytuł: Podstawy teologii moral$n e{ }^{25}$. Znaczy to, że zagadnienia podstawowe nie tylko doceniał, ale że nie schodziły one $\mathrm{z}$ Jego warsztatu pracy do ostatnich dni. Kiedyś rozważał problem: Czy teologia moralna ma szukać nowych dróg? ${ }^{26}$, a nawet spieral się o ten jej kształt, który wyrasta z ujęcia samych pod-

25 Poznań, 1969.

26 ,Polonia Sacra” 5 (1952) 238-253. 
staw. Widać, że sprawy te studiował wytrwale. Studiował je - i to jakby ze szczególnym zainteresowaniem wówczas - kiedy już mniej się wypowiadał na tematy aktualnej moralności społeczeństwa. Widocznie sama struktura zagadnień moralnych zmusza do szukania właściwych podstaw. Można od tego wychodzić w etyce czy teologii moralnej - ale musi się do tego powracać.

Tak więc droga naukowa, jaką przeszedł Ksiądz Profesor Władysław Wicher, wpisze się jako dalszy rozdział do tej genealogii uczonych, teologów i moralistów polskich w najstarszym polskim środowisku uniwersyteckim. Sam fakt istnienia takiej genealogii świadczy o tym, że uczony nie tylko odchodzi, ale także pozostaje w środowisku naukowym swej uczelni. Dali temu wyraz profesorowie krakowskiej Almae Matris z różnych Wydziałów, gdy w styczniu 1969 r. uczestniczyli w złotym jubileuszu pracy naukowej swego wieloletniego Kolegi z Wydziału Teologicznego. Szczególny wyraz znalazło to stanowisko w przemówieniu P. Rektora Władysława Szafera, który wspominał lata wspólnej pracy w Senacie - mówiąc o przeszłości, ale zarażem patrzył w przyszłość. Zapamiętaliśmy wszyscy tę mowę Rektora na złotym jubileuszu Księdza ProfesoraWichra. Wyraził się w niej właśnie ów jedyny w swoim rodzaju klimat środowiska. Wyraziła się wspólnota uniwersytecka, która jest wspólnotą ludzi, stale na nowo wyrastającą $\mathrm{z}$ wzajemnego przenikania się wielu umysłów i różnych dziedzin nauki. Wspólnota ta nie przestaje trwać w poszukiwaniu owej jedności, do której po wielu drogach zdąża ludzki umysł.

A genealogia uczonych $\mathrm{w}$ katedrze teologii moralnej przejmuje po Księdzu Profesorze Wichrze z całą pieczołowitością Jego dorobek - tak jak On przejmował dorobek swych poprzedników. W chwili odejścia Profesora teologia moralna znajduje się chyba bardziej jeszcze w poszukiwaniu swych dróg - wszystkich dróg, którymi powinna kroczyć niż w momencie, kiedy obejmował On tę katedrę. Jednakże poszukiwanie $w$ nauce jest już poniekąd znajdowaniem. I o tym wiedział Ks. Profesor Władysław Wicher przez tyle lat. I tej wiedzy pozostał wierny do ostatnich dni swojego życia. 